Check for updates

Cite this: RSC Adv., 2017, 7, 27853

Received 4th April 2017

Accepted 19th May 2017

DOI: $10.1039 / c 7 r a 03839 a$

rsc.li/rsc-advances

\section{Quantitative investigation of the decomposition of organic lithium ion battery electrolytes with LC- MS/MS}

\author{
Carola Schultz, ${ }^{a}$ Sven Vedder, ${ }^{\text {b }}$ Benjamin Streipert, ${ }^{a}$ Martin Winter ${ }^{\text {ac }}$ \\ and Sascha Nowak (iD *a
}

A novel high performance liquid chromatography (HPLC) hyphenated to tandem mass spectrometry (LCMS/MS) method for the separation and quantification of components from common organic carbonatebased electrolyte systems in lithium ion batteries (LIBs) was developed. The method development included the quantification of organic electrolyte main components as well as selected aging products in LIBs. The separation of these compounds was optimized and the limits of detection (LODs), limits of quantification (LOQs) and recovery rates were determined. For the analysis of substances without commercially available standard substances, a quantitative approach was conducted. In this study, four different lithium hexafluorophosphate $\left(\mathrm{LiPF}_{6}\right)$-based lithium ion battery (LIB) electrolytes were analyzed. These electrolyte samples were aged thermally (storage for two weeks at $60{ }^{\circ} \mathrm{C}$ and storage for two weeks at $60{ }^{\circ} \mathrm{C}$ with addition of 2 vol\% water) and electrochemically $\left(100\right.$ cycles at $2 \mathrm{C}$ at $20{ }^{\circ} \mathrm{C}$ and $60{ }^{\circ} \mathrm{C}$ and 100 cycles with higher upper cut-off potentials about $4.95 \mathrm{~V}, 5.20 \mathrm{~V}$ and $5.60 \mathrm{~V} \mathrm{vs.} \mathrm{Li}^{\circ} / \mathrm{Li}^{+}$). Thermal aging with the addition of water increased the amount of oligocarbonates in the electrolytes compared to thermal aging without the addition of water. Accordingly, the amounts of the main constituents decreased. After electrochemical aging at $20{ }^{\circ} \mathrm{C}$, larger amounts of oligocarbonates and triethyl phosphate (TEP) were generated compared to electrochemical aging at $60{ }^{\circ} \mathrm{C}$. Cycling with higher upper cut-off potentials led to the elevated formation of aging products in general.

\section{Introduction}

Due to their high energy density and high specific energy, LIBs belong to the most used battery types in the world for handheld devices and automotive applications. ${ }^{\mathbf{1 , 2}}$ However, the main disadvantage is the limited lifetime due to aging processes accompanied by capacity fading. ${ }^{3,4}$

In order to understand and minimize aging effects inside the electrolyte, novel analytical methods for the investigation of electrolyte components in LIBs are required. Mass spectrometry techniques for the quantification of electrolyte compounds are very important as exact amounts of components are determined with overall low LOQs. With this knowledge, the discussion of decomposition mechanisms is facilitated due to the fact that the increase or decrease of certain constituents and the associated kinetics of the reactions may be correlated to different aging procedures. A LIB usually consists of a carbon/graphite

${ }^{a}$ University of Münster, MEET Battery Research Center, Institute of Physical Chemistry, Corrensstraße 46, 48149 Münster, Germany.E-mail: sascha.nowak@uni-muenster.de; Fax: +49-251-83-36032

${ }^{b}$ Shimadzu Europa GmbH, Albert-Hahn-Straße 6-10, 47269 Duisburg, Germany

${ }^{c}$ Helmholtz Institute Münster (HI MS), IEK-12, Forschungszentrum Jülich GmbH, Corrensstraße 46, 48149 Münster, Germany based anode, a lithium transition metal oxide cathode and an electrolyte soaked polyolefin-based separator. ${ }^{5,6}$ The electrolyte provides ionic conductivity and consists of mixture of organic solvents and at least one conducting salt. Typically, the solvents in the electrolyte are a mixture of cyclic and linear organic carbonates like ethylene carbonate (EC), dimethyl carbonate (DMC), ethyl methyl carbonate (EMC) and diethyl carbonate (DEC). ${ }^{7}$ Nowadays, the most applied conducting salt is lithium hexafluorophosphate $\operatorname{LiPF}_{6}{ }^{8,9}$ While $^{\mathbf{8}} \mathrm{LiPF}_{6}$ is essential for the protection of the used $\mathrm{Al}$ current collector, ${ }^{\mathbf{1 0}}$ the disadvantage of $\mathrm{LiPF}_{6}$ is its chemical and thermal instability in organic carbonates towards the $\mathrm{P}-\mathrm{F}$ bond which is one reason for electrolyte aging and has initiated substantial research efforts in view of the synthesis of alternative salts. ${ }^{11}$ So far, however, $\mathrm{LiPF}_{6}$ could not be replaced in commercial LIB electrolytes.

$\mathrm{LiPF}_{6}$ forms an equilibrium with $\mathrm{LiF}$ and $\mathrm{PF}_{5}$. The formation of aging products starts with the reaction of organic carbonates with $\mathrm{PF}_{5}$. Further, transesterification reactions between the organic carbonates occur in the electrolyte. ${ }^{\mathbf{1 2 - 1 4}}$ Another decomposition pathway is the electrochemical reaction of electrolyte compounds at the charged anode. These decomposition products, particularly from EC, build a protective layer on the anode, the solid electrolyte interphase (SEI). ${ }^{15,16}$ A schematical overview of selected aging mechanisms for the aging 
products that were investigated in this study is shown in Fig. 1. One aging mechanism is the trans-esterification of EMC to DMC and DEC (Fig. 1 pathway (a)). ${ }^{\mathbf{1 2 - 1 4 , 1 7 , 1 8}} \mathrm{PF}_{5}$ is a lewis acid and even reacts with traces of water. ${ }^{19}$ In case of water contaminations, the resulting $\mathrm{POF}_{3}$ is hydrolyzed in several steps to difluorophosphoric acid, monofluorophosphoric acid and phosphoric acid. ${ }^{20}$ Subsequent reactions may occur which produce organophosphate-based and organic fluorophosphatebased aging products. Organic fluorophosphate-based aging products are generated due to the reaction of $\mathrm{POF}_{3}$ with the organic carbonates, shown in Fig. 1, pathway (c). The reaction of $\mathrm{HPO}_{2} \mathrm{~F}_{2}$ with organic carbonates leads to the generation of the phosphate-based aging products (pathway (d)). By hydrolysis, the organic fluorophosphate-based aging products may react to organophosphate-based aging products. Oligomeric carbonate species are formed due to the electrochemically induced ring opening of EC and a subsequent reaction with linear organic carbonates. In general, one equivalent EC and two equivalents of linear organic carbonates react (Fig. 1, pathway (b)).

Several analytical techniques for the quantification of LIB electrolyte components were published so far in literature. The quantification of organic carbonates in LIBs from hybrid electric vehicles was done by Grützke et al. with the gas chromatography flame ionization detector (GC-FID) technique. ${ }^{21}$ The quantitative analysis of organic carbonates and the additive vinylene carbonate (VC) with HPLC ultraviolet visible (UV/VIS) detection was performed in our previous works. ${ }^{223}$ The quantification of two organophosphates, dimethyl fluorophosphate (DMFP) and diethyl fluorophosphate (DEFP) in aged LIB electrolytes with LC-MS/MS was conducted by Kraft et al. ${ }^{24}$ They found elevated amounts of DMFP and DEFP in electrolytes aged at $95{ }^{\circ} \mathrm{C}$ and in LIBs treated electrochemically at $5.5 \mathrm{~V}$. Wagner et al. have shown the importance of these compounds for electrochemical performance. ${ }^{25}$ Weber et al. published a method for the quantification of DMFP and DEFP with GCMS. ${ }^{26}$ The hydrofluoric acid concentration in LIB electrolytes was quantified in the work of Lux et al. by applying a method measuring the $\mathrm{SiO}_{2}$ loss. ${ }^{27}$ Tochihara et al. studied the decrease and increase of peak intensities after formation and after cycling the cells at $60{ }^{\circ} \mathrm{C}$. They found an increase in organo fluorophosphates and a decrease in carbonate-based aging products. They claimed that this decrease probably occurred because the carbonate polymers are modified compounds originating from components of the SEI generated during formation. $^{28}$

In this study, a LC-MS/MS method for the quantification of LIB electrolyte main constituents (EC, DMC, EMC, DEC) and selected carbonate-based aging products (2,5-dioxahexanedioic acid dimethyl ester (DMDOHC) and 2,5-dioxahexanedioic acid diethyl ester) as well as organophosphate-based aging products

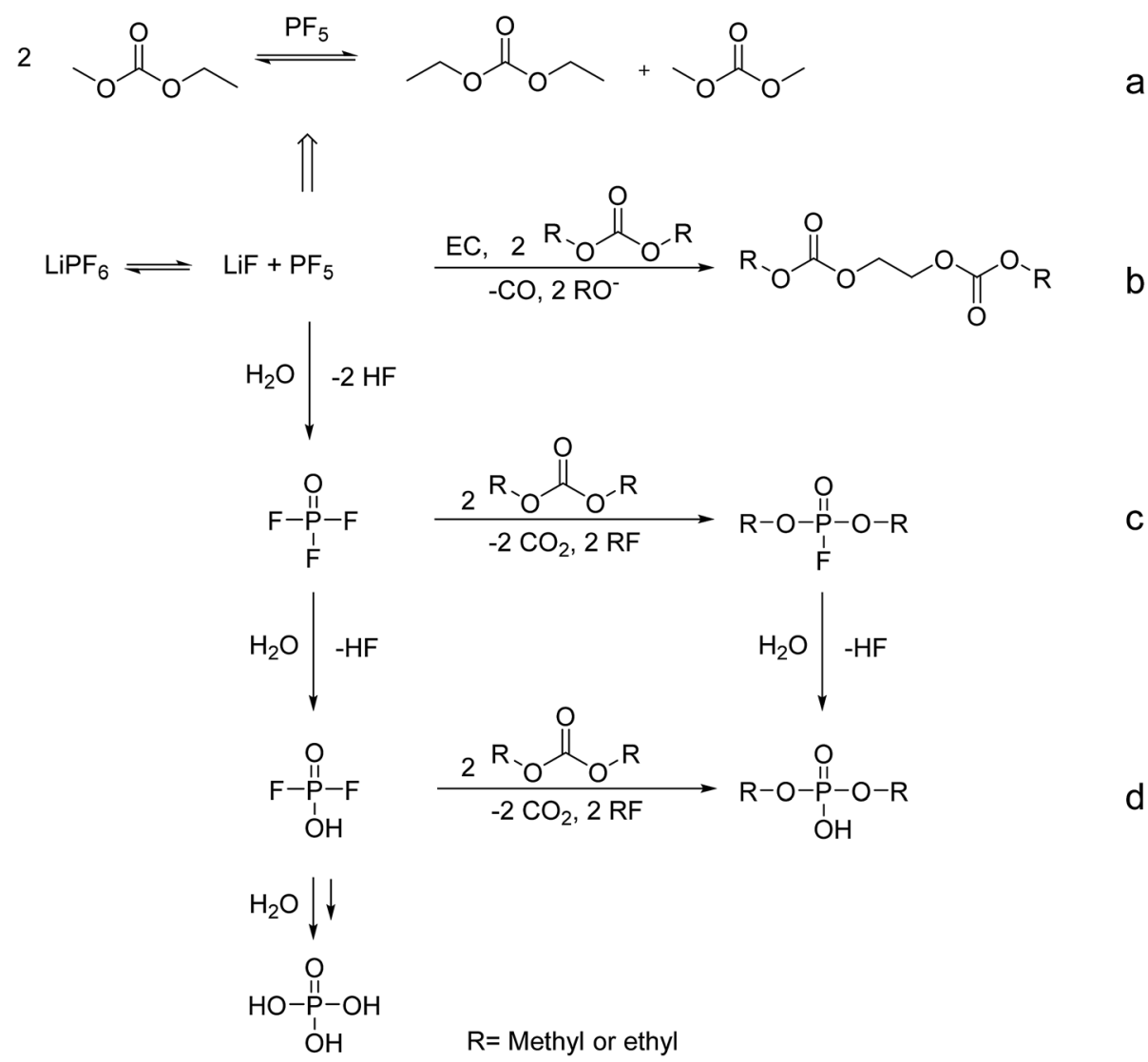

Fig. 1 General decomposition paths for the formation of trans-esterification products (pathway (a)), oligocarbonate-based aging products (pathway (b)), organophosphate-based aging products (pathway (c)) and organic fluorophosphate-based aging products (pathway (d)), adapted and extended from. ${ }^{42-47}$ 
(dimethyl phosphate (DMP), diethyl phosphate (DEP) and triethyl phosphate (TEP)) in thermally and electrochemically treated electrolytes was carried out. Additionally, a quantitative approach was performed for the determination of the change in signal intensities from oligocarbonate-based aging products. Four different electrolytes were investigated in this study: LP30 (1/1 wt/wt DMC/EC and $\left.1 \mathrm{M} \mathrm{LiPF}_{6}\right), \mathrm{LP} 40$ (1/1 wt/wt DEC/EC and $1 \mathrm{M} \mathrm{LiPF}_{6}$ ), LP50 (1/1 wt/wt EMC/EC and $\left.1 \mathrm{M} \mathrm{LiPF}_{6}\right)$ and LP71 (1/ $1 / 1 \mathrm{wt} / \mathrm{wt} / \mathrm{wt} \mathrm{EC} / \mathrm{DMC} / \mathrm{DEC}$ and $\left.1 \mathrm{M} \mathrm{LiPF}_{6}\right)$. In order to investigate changes in the concentration of these substances and their correlation to different aging parameters, three different aging procedures, each with at least two different aging parameters for comparison, were conducted: thermal aging at $60{ }^{\circ} \mathrm{C}$ and thermal aging at $60{ }^{\circ} \mathrm{C}$ with the addition of water, electrochemical aging at $20^{\circ} \mathrm{C}$ and $60^{\circ} \mathrm{C}$ and electrochemical aging at different upper cut-off potentials $(4.95 \mathrm{~V}, 5.20 \mathrm{~V}$ and $5.60 \mathrm{~V} v$ s. $\left.\mathrm{Li} / \mathrm{Li}^{+}\right)$. The advantage of this LC-based technique compared to GC-based techniques is the possibility to investigate analytes with high molecular masses. The substances with higher masses have also higher boiling points or decompose during heating up. In this case, LC is a better choice for analysis as also these substances can be analyzed. In general, LC is a soft technique because the analytes are not heated.

\section{Experimental part}

\subsection{Chemicals}

Methanol (LC-MS Chromasolv) was obtained from Fluka/Sigma Aldrich (Steinheim, Germany) and ultrapure water (LC-MS Chromasolv) from Fluka/Sigma Aldrich (St. Gallen, Switzerland). Formic acid was purchased from Merck (Darmstadt, Germany). Argon with a purity of 5.7 was obtained from BIP ${ }^{\circledR}$ (Crewe, United Kingdom). Nitrogen (purity: 99.5\%) was produced with a generator. The electrolytes SelectiLyte ${ }^{\mathrm{TM}}$ LP30 ( $1 / 1 \mathrm{wt} / \mathrm{wt} \mathrm{DMC/EC} \mathrm{and} 1 \mathrm{M} \mathrm{LiPF}_{6}$ ), LP40 (1/1 wt/wt DEC/EC and $\left.1 \mathrm{M} \mathrm{LiPF}_{6}\right)$, LP50 (1/1 wt/wt EMC/EC and $\left.1 \mathrm{M} \mathrm{LiPF}_{6}\right)$ and LP71 (1/ $1 / 1 \mathrm{wt} / \mathrm{wt} / \mathrm{wt} \mathrm{EC} / \mathrm{DMC} / \mathrm{DEC}$ and $1 \mathrm{M} \mathrm{LiPF}_{6}$ ) and organic carbonates with battery grade purity were ordered from BASF (Ludwigshafen, Germany). 2,5-Dioxahexanedioic acid dimethyl ester (DMDOHC) and 2,5-dioxahexanedioic acid diethyl ester (DEDOHC), both a purity of $98 \%$, were purchased from abcr GmbH (Karlsruhe, Germany). Dimethyl phosphate (DMP): purity: $98 \%$, determined during the experiments by nuclear magnetic resonance (NMR) spectroscopy due to the reactivity of the compound, diethylphosphate (DEP, 99\%) and triethyl phosphate (TEP, 99.8\%) were bought from Sigma Aldrich (Steinheim, Germany). All structures can be found in Fig. 1 and 5 .

\subsection{Cell assembly and cycling}

The lithium ion full cells were built in a two electrode pouch bag cell setup. The cell geometry of a pouch bag cell is rectangular, thin and consists of two electrodes that were arranged together with a separator in a linear, stacked setup. The case is made of a flexible aluminum laminated multilayer foil. In-house made lithium nickel manganese cobalt oxide (NMC-111) and mesophase carbon microbeads (MCMB) electrodes were used as cathode and anode, respectively. The electrodes with dimensions of $3 \times 3 \mathrm{~cm}$ had aluminum and copper current collectors. As electrolyte, LP30, LP40 and LP50 were used, each cell was filled with $375 \mu \mathrm{L}$ electrolyte. The one layered separator between anode and cathode was Freudenberg 2190 (polypropylene fleece, Freudenberg, Germany). The pouch cells were assembled in a dry room with a dew point about $-65^{\circ} \mathrm{C}$.

For the investigations at different upper cut-off potentials, half cells were built in a T-half cell setup. This consists of a working, counter and reference electrode (WE, CE, RE). The electrodes for the half cells had a diameter of $12 \mathrm{~mm}$. The WE was lithium nickel manganese oxide (LNMO) and lithium metal electrodes were used as CE and RE. Two separator stacks (Freudenberg 2190), each made from six sheets, were placed in the half cell, one between WE and CE and one at the reference electrode. $200 \mu \mathrm{L}$ of the electrolyte were filled into the half cells on the separators. The cells were assembled in an argon-filled glovebox (MEGA Line, mBraun, Garching, Germany) with oxygen and water contents lower than $1 \mathrm{ppm}$.

The assembled the cells were cycled with a MACCOR Model 4300 battery tester (Maccor, USA) in a climatic test chamber (KB 400 , Binder, Germany) set to $20{ }^{\circ} \mathrm{C}$ and $60{ }^{\circ} \mathrm{C}$ for full cells, respectively. The used voltage range was $2.8-4.15 \mathrm{~V}$ for the full cells. The formation procedure consisted of two cycles with a constant-current-constant-voltage (CCCV) step at a charge rate (C-rate; C) with $0.1 \mathrm{C}$ for 3 cycles followed by a CCCV cycling step at $0.5 \mathrm{C}$ for 3 cycles. Afterwards, the cells were cycled with a CCCV step at $2.0 \mathrm{C}$ for 100 cycles. The discharge steps with the corresponding specific currents were performed with a constant-current cycling step. For reproducibility reasons, two cells were built for each cell experiment.

For the electrochemical aging investigations of the half cells, three different upper cut-off potentials were used. The cells were cycled in a potential range from $3.0 \mathrm{~V}$ to $4.95 \mathrm{~V}, 5.20 \mathrm{~V}$ and $5.60 \mathrm{~V}$ $v s$. $\mathrm{Li} / \mathrm{Li}^{+}$. The cycling procedure contained a formation step with a CC step and a C-rate of $0.2 \mathrm{C}$ for 3 cycles. A subsequent CC step with 1.0C for 100 cycles was applied after formation. For reproducibility reasons, all cells were investigated twice.

\subsection{Thermal aging}

5 mL of electrolyte (LP 30, LP40 and LP 71) were given into a gastight aluminum vessel and stored at $60{ }^{\circ} \mathrm{C}$ for two weeks. For thermal aging with water addition, the samples were prepared in the same way but $100 \mu \mathrm{L}$ water $(2 \mathrm{vol} \%)$ were added to the electrolyte.

\subsection{LC-MS/MS conditions}

For quantitative investigations of electrolytes with LC-MS/MS, a UHPLC NexeraX2 LC-30 System from Shimadzu (Kyoto, Japan) was used. The hyphenated mass spectrometer was a LCMS-8040 from Shimadzu (Kyoto, Japan).

For ionization of the substances, electrospray ionization was used in the positive ion mode with an interface probe voltage of $5 \mathrm{kV}$. In order to gain the highest sensitivity and selectivity, the MRM mode was applied. The desolvation line temperature was 
$230{ }^{\circ} \mathrm{C}$ and the heat block temperature $200{ }^{\circ} \mathrm{C}$. The conversion dynode was set to $10 \mathrm{kV}$. The nebulizing gas flow was $3 \mathrm{~L} \mathrm{~min}^{-1}$ and the drying gas flow (both nitrogen) $15 \mathrm{~L} \mathrm{~min}^{-1}$. As gas for the collision-induced dissociation (CID), argon was used with a pressure of $130 \mathrm{kPa}$. The mass range for the product ion scan mode was set between 80-350 Da.

The eluent used consisted of mobile phase A (aqueous 0.1 vol\% formic acid solution for a more efficient ionization) and mobile phase $\mathrm{B}$ (methanol) with a flow rate of $0.4 \mathrm{~mL} \mathrm{~min}^{-1}$. The used gradient is described in the following: $0 \mathrm{~min}, 2 \% \mathrm{~B}$; $2.5 \mathrm{~min}, 2 \% \mathrm{~B}$; $25 \mathrm{~min}, 55 \% \mathrm{~B}$; $28 \mathrm{~min}, 90 \% \mathrm{~B} ; 29 \mathrm{~min}, 90 \% \mathrm{~B}$; $29.01 \mathrm{~min}, 2 \% \mathrm{~B}, 30 \mathrm{~min}, 2 \% \mathrm{~B}$. The column oven was tempered to $40{ }^{\circ} \mathrm{C}$. As stationary phase, an ACE Excel $\mathrm{C}_{18}$-PFP column with $14.3 \%$ carbon and integrated pentafluorophenyl functionality was used. The dimensions were $2.1 \mathrm{~mm} \times 100 \mathrm{~mm}$, the pore size was $100 \AA$ and the particle size $2 \mu \mathrm{m}$.

The injection volume of the samples was set to $0.1 \mu \mathrm{L}$ for the optimization of the substances and to $1 \mu \mathrm{L}$ during quantification. The whole system was controlled by LabSolutions LCMS (Version 5.80) (Shimadzu, Kyoto, Japan). Each electrolyte sample and self-assembled cell was double investigated and measured three times to verify the reproducibility of the results.

\subsection{Sample preparation}

After galvanostatic cycling, the pouch cells were opened in a dry room. The separator was quickly taken out of the cell and given into a $1.5 \mathrm{~mL}$ Eppendorf Safe Lock Tube in order to prevent electrolyte evaporation. The Safe Lock Tube contained an inserted pipette tip to act as distance piece between the bottom of the Safe Lock Tube and the separator. With a Galaxy SD Microcentrifuge (VWR International GmbH, Germany) the SafeLock Tube containing the separator was centrifuged for 15 minutes at 8500 rounds per minute. With this method, the electrolyte accumulated on the bottom of the vial and was removed pure for LC-MS measurements. For optimization measurements, the following substances were diluted with methanol: EC, DMC, EMC, DEC were diluted 1/1000 (v/v), DMDOHC and DEDOHC 1/100 $000(\mathrm{v} / \mathrm{v})$. DMP and DEP were diluted 1/10 $000(\mathrm{v} / \mathrm{v})$ and TEP 1/40 $000(\mathrm{v} / \mathrm{v})$. All electrolytes extracted out of the LIBs were diluted $1 / 5000(\mathrm{v} / \mathrm{v})$ with methanol.

\section{Results and discussion}

\subsection{MRM mode optimization}

For the optimization of the multiple reaction monitoring (MRM) mode, the precursor ion, the product ions as well as the collision energy and the pre-rod bias voltage for quadrupole 1 and 3 of each used standard substance are of importance. ${ }^{29}$ The optimization of these device parameters, adapted to each substance, was performed automatically without a column. The substances with the chosen precursor ions and the fragments are shown in Table 1 . All quantified substances were separated on a $\mathrm{C}_{18}$-PFP column. The corresponding retention times are listed in Table 1.

For the oligocarbonates EMDOHC, oligocarbonate (OC) 1, OC 2 and OC 3, no standards were commercially available. Because of this, a quantitative approach by the determination of the peak areas was conducted for these four substances. Therefore, the substances were optimized with an aged electrolyte sample containing these aging products. The optimization was conducted automatically with a $\mathrm{C}_{18}$-PFP column by the knowledge of the retention times for the substances.

The LOD and LOQ values for all quantified substances are listed in Table 2. Due to the increased sensitivity which is obtained by the highly sensitive and selective MRM mode, low LODs and LOQs were determined. The presented method is a valuable amendment to the previous work with the LC-IT-TOFMS technique and the HPLC-UV/VIS in LIB electrolyte research. ${ }^{22,30}$

Furthermore, the recovery rates of all quantified substances were determined. For the determination of the organic carbonates, fresh electrolytes were measured and the determined amount was referred to the theoretical amount of organic carbonate into the electrolyte. For the aging products DMDOHC, DEDOHC, DMP, DEP and TEP, no standard electrolytes with reference amounts were available. Therefore,

Table 1 Investigated substances with optimized precursor, quantifier and qualifiers

\begin{tabular}{|c|c|c|c|c|c|c|}
\hline Substance (abbreviation) & Ion & $t_{\mathrm{R}}[\min ]$ & $\begin{array}{l}\text { Precursor ion } \\
{[\mathrm{m} / \mathrm{z}]}\end{array}$ & $\begin{array}{l}\text { Quantifier } \\
\text { ion }[\mathrm{m} / \mathrm{z}]\end{array}$ & $\begin{array}{l}\text { Qualifier } 1 \\
\text { ion }[m / z]\end{array}$ & $\begin{array}{l}\text { Qualifier } 2 \\
\text { ion }[\mathrm{m} / \mathrm{z}]\end{array}$ \\
\hline DMP & {$[\mathrm{M}+\mathrm{H}]^{+}$} & 0.7 & 126.80 & 109.00 & 95.00 & 33.00 \\
\hline DEDOHC & {$[\mathrm{M}+\mathrm{H}]^{+}$} & 19.2 & 206.80 & 89.00 & 117.05 & 45.05 \\
\hline DMDOHC & {$[\mathrm{M}+\mathrm{H}+\mathrm{MeOH}]^{+}$} & 10.9 & 210.80 & 103.05 & 59.05 & 31.05 \\
\hline EMC & {$\left[\mathrm{M}-\mathrm{C}_{2} \mathrm{H}_{4}+\mathrm{H}+\mathrm{MeOH}\right]^{+}$} & 7.8 & 108.80 & 77.10 & 59.10 & 45.00 \\
\hline DEC & {$[\mathrm{M}+\mathrm{H}]^{+}$} & 13.1 & 118.85 & 63.00 & 91.05 & 87.10 \\
\hline TEP & {$[\mathrm{M}+\mathrm{H}]^{+}$} & 16.7 & 182.80 & 99.00 & 127.00 & 80.95 \\
\hline EMDOHC & {$[\mathrm{M}+\mathrm{H}+\mathrm{MeOH}]^{+}$} & 16.0 & 224.90 & 103.10 & 117.05 & 89.05 \\
\hline OC 1 & {$[\mathrm{M}+\mathrm{H}]^{+}$} & 17.2 & 266.80 & 103.10 & 59.05 & - \\
\hline OC 2 & {$[\mathrm{M}+\mathrm{H}]^{+}$} & 20.4 & 280.85 & 103.10 & 117.10 & 89.05 \\
\hline OC 3 & {$[\mathrm{M}+\mathrm{Na}]^{+}$} & 23.3 & 316.75 & 228.70 & 88.75 & - \\
\hline
\end{tabular}


Table 2 LOD and LOQ determined on the $C_{18}$-PFP column in the LC-MS/MS MRM mode for standard samples in ppb together with the recovery rates

\begin{tabular}{|c|c|c|c|c|c|c|c|c|c|}
\hline & EC & DMC & EMC & DEC & DMDOHC & DEDOHC & DMP & DEP & TEP \\
\hline LOD [ppb] & 613 & 2100 & 1000 & 98.0 & 4.1 & 0.7 & 132 & 7.7 & 0.2 \\
\hline LOQ [ppb] & 1800 & 6400 & 3000 & 294 & 12.4 & 1.4 & 396 & 12.8 & 0.6 \\
\hline
\end{tabular}

a standard mixture was prepared for the determination of the theoretical amount inside the mixture. The recovery rates are listed in Table 2.

\subsection{Quantification results}

During the quantification with the LC-MS/MS device, the signal intensity of all quantified substances decreased due to a typical device drift. This decrease was compensated with calculated correction factors which were determined for each substance. For this purpose, one reference sample containing all investigated substances was measured in constant intervals distributed over the amount of samples. In this way, the intensity decrease of each substance during the measurements was monitored.

The quantification results in this chapter were always referred to $g$ substance per L electrolyte. Ion suppression effects were neglected due to the fact that on the one hand, a column was used for the separation and on the other hand, all electrolyte samples were diluted $1 / 5000(\mathrm{v} / \mathrm{v}) \cdot{ }^{31-33}$

3.2.1 Quantification results of thermal aging. The quantification results are listed in Table 3 and displayed graphically in Fig. 1. Thermal aging of LP30 at $60{ }^{\circ} \mathrm{C}$ led to the generation of $1.9 \mathrm{~g} \mathrm{~L}^{-1} \pm 0.2 \mathrm{~g} \mathrm{~L}^{-1} \mathrm{DMDOHC}$ and $3.2 \times 10^{5} \mathrm{cps} \pm 0.2 \times 10^{5}$ cps signal area of OC 1 . Thermal aging in the presence of $2 \mathrm{vol} \%$ water increased the amount of DMDOHC and OC 1 significantly $\left(68.3 \mathrm{~g} \mathrm{~L}^{-1} \pm 2.8 \mathrm{~g} \mathrm{~L}^{-1}\right.$ and $90.8 \times 10^{5} \mathrm{cps} \pm 3.1 \times 10^{5}$ cps signal area). Additionally, $29.5 \mathrm{~g} \mathrm{~L}^{-1} \pm 2.1 \mathrm{~g} \mathrm{~L}^{-1} \mathrm{DMP}$ were quantified after thermal aging with water. As the aging products were generated due to reactions of the main constituents, these were supposed to decrease. This assumption was confirmed as the amounts from EC and DMC were $518 \mathrm{~g} \mathrm{~L}^{-1} \pm 14 \mathrm{~g} \mathrm{~L}^{-1}$ and $507 \mathrm{~g}$ $\mathrm{L}^{-1} \pm 37 \mathrm{~g} \mathrm{~L}^{-1}$ after thermal aging and decreased to $484 \mathrm{~g} \mathrm{~L}^{-1} \pm$ $25 \mathrm{~g} \mathrm{~L}^{-1} \mathrm{EC}$ and $381 \mathrm{~g} \mathrm{~L}^{-1} \pm 28 \mathrm{~g} \mathrm{~L}^{-1} \mathrm{DMC}$ after thermal aging in the presence of water. Thermal aging with LP40 showed the generation of $0.67 \mathrm{~g} \mathrm{~L}^{-1} \pm 0.01 \mathrm{~g} \mathrm{~L}^{-1}$ DEDOHC.

The quantification results of the investigated electrolytes LP40 and LP71 showed similar results. In the case of LP40, thermal aging with water accelerated the DEDOHC formation and led to the additional formation of DEP, TEP and OC 3 in the electrolyte. The content of organic carbonates decreased comparing thermal aging and thermal aging in the presence of water due to accelerated aging reactions in the water containing samples.

Since LP71 contains DMC and DEC, the methyl- and ethylgroup containing aging product DMDOHC, EMDOHC and DEDOHC were detected in the sample aged at $60{ }^{\circ} \mathrm{C}$. Thermal aging at $60{ }^{\circ} \mathrm{C}$ with 2 vol\% water showed the additional generation of DEP, TEP, OC 1 and OC 2 and significantly increased amounts of DMDOHC, EMDOHC and DEDOHC. Again, the decreasing amounts of organic carbonates in the thermally aged, water containing sample correlated to the increased amounts of aging products.

Table 3 Quantified amounts of DMDOHC, DEDOHC, DMP, DEP, TEP and the organic carbonates EC, DMC and DEC in electrolytes after thermal aging at $60^{\circ} \mathrm{C}$ and after thermal aging with 2 vol\% water together with the quantitative approach with the signal areas of EMDOHC, OC $1, \mathrm{OC} 2$ and $\mathrm{OC} 3$

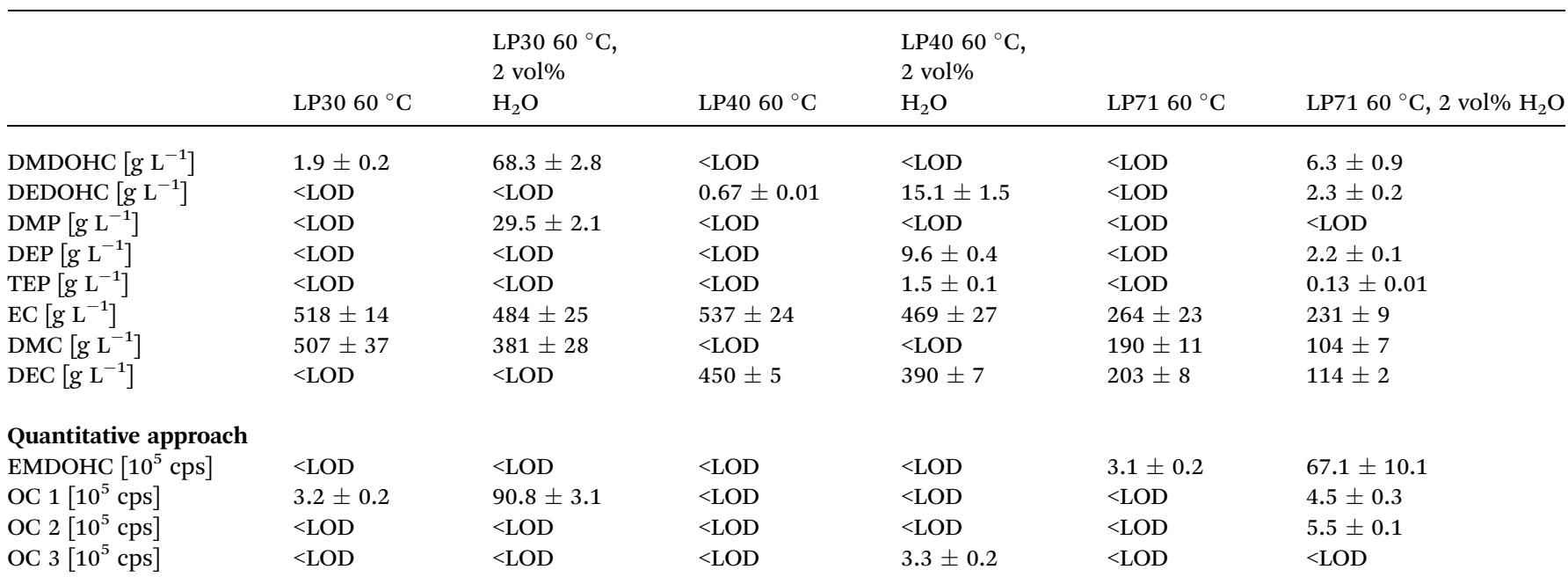


In general, after thermal aging of the electrolytes, carbonatebased aging products were formed. After thermal aging of the electrolytes with water addition, carbonate-based aging products and additionally phosphate-based aging products were generated. Comparing the aging of electrolytes LP30, 40 and 71, it is obvious, that the structures of the aging products origin from the content of the initial electrolytes. Aged LP30 contained only aging products with dimethyl groups whereas aged LP40 contained only aging products with diethyl groups. Compared to LP71, all kind of aging products with dimethyl groups, diethyl groups and methylethyl groups were formed. With these results of the experiments, it was evidenced that the alkyl groups of the organic carbonates from the initial electrolytes can be found in the aging products according to the reactions shown in Fig. 1.

The water consumption of the electrolytes during thermal aging with 2 vol\% water was determined by Karl Fischer titration. Therefore, the water content of the samples was measured directly after the water addition to the electrolytes. The initial water content of all samples was $14599 \mathrm{ppm} \pm 27 \mathrm{ppm}$. After two weeks, the electrolytes contained only 1415 ppm \pm 78 ppm water, the water content was reduced during aging reactions within these two weeks. The water content after two weeks thermal aging at $60{ }^{\circ} \mathrm{C}$ was $556 \mathrm{ppm} \pm 57 \mathrm{ppm}$ for LP30, $464 \mathrm{ppm} \pm 15 \mathrm{ppm}$ for LP40 and $474 \mathrm{ppm} \pm 2 \mathrm{ppm}$ for LP71. The elevated water consumption indicates the accelerated aging reactions that occurred in the thermally aged electrolytes containing water. The results of an increased water consumption at $60{ }^{\circ} \mathrm{C}$ were confirmed by the high amount of generated aging products inside the electrolytes.

\subsubsection{Quantification results of electrochemical aging}

3.2.2.1 Cycling at $20^{\circ} \mathrm{C}$ and $60^{\circ} \mathrm{C}$. The quantification results and the peak areas for the quantitative approach are listed in Table 4 and shown graphically in Fig. 2. After electrochemical aging at $20{ }^{\circ} \mathrm{C}$ of the cell containing LP30, $202 \mathrm{~g} \mathrm{~L}^{-1} \pm 6 \mathrm{~g} \mathrm{~L}^{-1}$ DMDOHC were found in the electrolyte. The amount decreased to $112 \mathrm{~g} \mathrm{~L}^{-1} \pm 2 \mathrm{~g} \mathrm{~L}^{-1}$ compared to the cell cycled at $60^{\circ} \mathrm{C}$. TEP was generated in an amount of $0.11 \mathrm{~g} \mathrm{~L}^{-1} \pm 0.01 \mathrm{~g} \mathrm{~L}^{-1}$ in the cell cycled at $20{ }^{\circ} \mathrm{C}$ and $0.09 \mathrm{~g} \mathrm{~L}^{-1} \pm 0.01 \mathrm{~g} \mathrm{~L}^{-1}$ in the cell cycled at $60{ }^{\circ} \mathrm{C}$. At $20^{\circ} \mathrm{C}$, the signal area of OC 1 was $232 \times 10^{5} \pm 28 \times 10^{5}$ cps. After cycling at $60^{\circ} \mathrm{C}$, the signal area decreased to $120 \times 10^{5}$ $\pm 3 \times 10^{5}$ cps.
Concerning the results of electrochemical aging, all cells showed a similar trend: the cells containing LP40 cycled at $20{ }^{\circ} \mathrm{C}$ showed elevated amounts of DEDOHC, TEP and OC 3 compared to the cells cycled at $60{ }^{\circ} \mathrm{C}$. This trend is probably explained due to a different temperature behaviour of the SEI. ${ }^{7,34,35}$

The same trend appeared in the cell with LP50. DMDOHC, EMDOHC, OC 1, OC 2, OC 3 and TEP were present in significantly higher amounts in the cell cycled at $20{ }^{\circ} \mathrm{C}$. Furthermore, the amount of DEC which was generated by transesterification reactions, decreased in the cell cycled at $60{ }^{\circ} \mathrm{C}$.

The amount of DMDOHC was several times higher in the cell with LP30 compared to the cells that contained LP40 and LP50, cycled at $20{ }^{\circ} \mathrm{C}$. This might be explained by the fact that DMC is a known, less toxic methylation reagent. ${ }^{36-38}$ This fact was studied from Arico et al., they investigated also the reaction mechanisms of DMC and its selective behavior in reaction with different nucleophiles. ${ }^{36}$ Furthermore, they consider the principle of hard and soft acids and bases (HSAB) in the reaction behavior of DMC. As result of their study, they showed that at complete conversion of the substrate the selectivity for the monomethylated product is often $>99 \%{ }^{30}$

In general, a clear trend was observed for the temperature dependence in all investigated cells: interestingly, at $60{ }^{\circ} \mathrm{C}$, the amounts of generated aging products (carbonate-based aging products and phosphate-based aging products) were significantly lower compared to the cells cycled at $20^{\circ} \mathrm{C}$. These results were further confirmed by the decreasing signal areas at $60{ }^{\circ} \mathrm{C}$ determined with the quantitative approach. The signal areas of the aging products decreased in the cells cycled at $60{ }^{\circ} \mathrm{C}$ compared to the cells cycled at $20{ }^{\circ} \mathrm{C}$. Tochihara et al. investigated aging products in the SEI and found a decrease of some carbonate-based aging products in the SEI after cycling at $60{ }^{\circ} \mathrm{C}$ compared to cells investigated after formation. ${ }^{28}$ Based on our findings and the results of Tochihara et al., it is assumed, that there is an equilibrium between the components in the SEI and in the electrolyte. Furthermore, Andersson et al. reported that the SEI decomposed partially at elevated temperatures. After heating to $200{ }^{\circ} \mathrm{C}$, the SEI completely decomposed..$^{39}$ They also claimed that the SEI is more porous at elevated temperatures, with partial exposing of the graphite surface. The formation of inorganic SEI species was favored at higher temperatures. ${ }^{35}$ These results let assume that the oligocarbonates in the

Table 4 Quantified amounts of DMDOHC, DEDOHC and TEP in full cells with different electrolytes, cycled at $20^{\circ} \mathrm{C}$ and $60^{\circ} \mathrm{C}$ together with the quantitative approach with the signal areas of EMDOHC, OC 1, OC 2 and OC 3

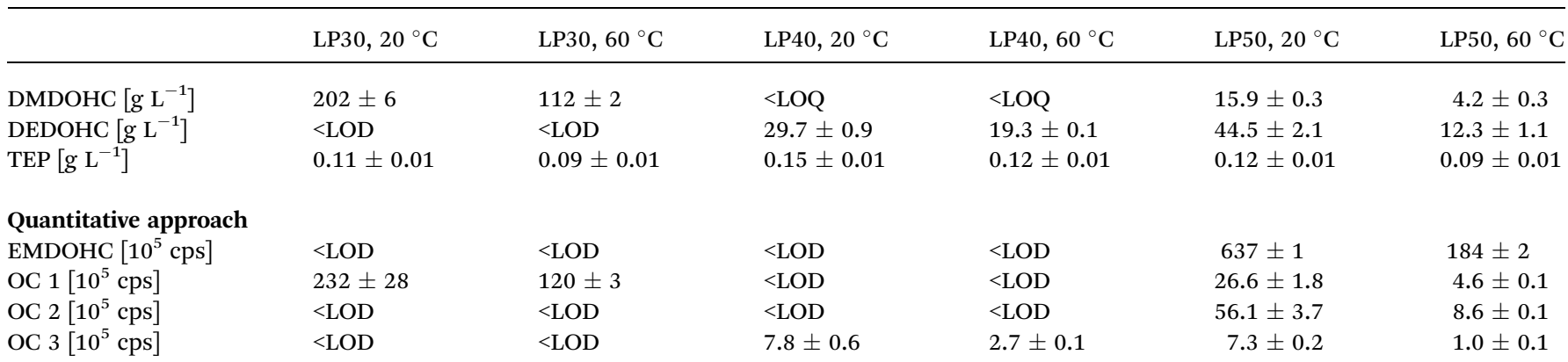



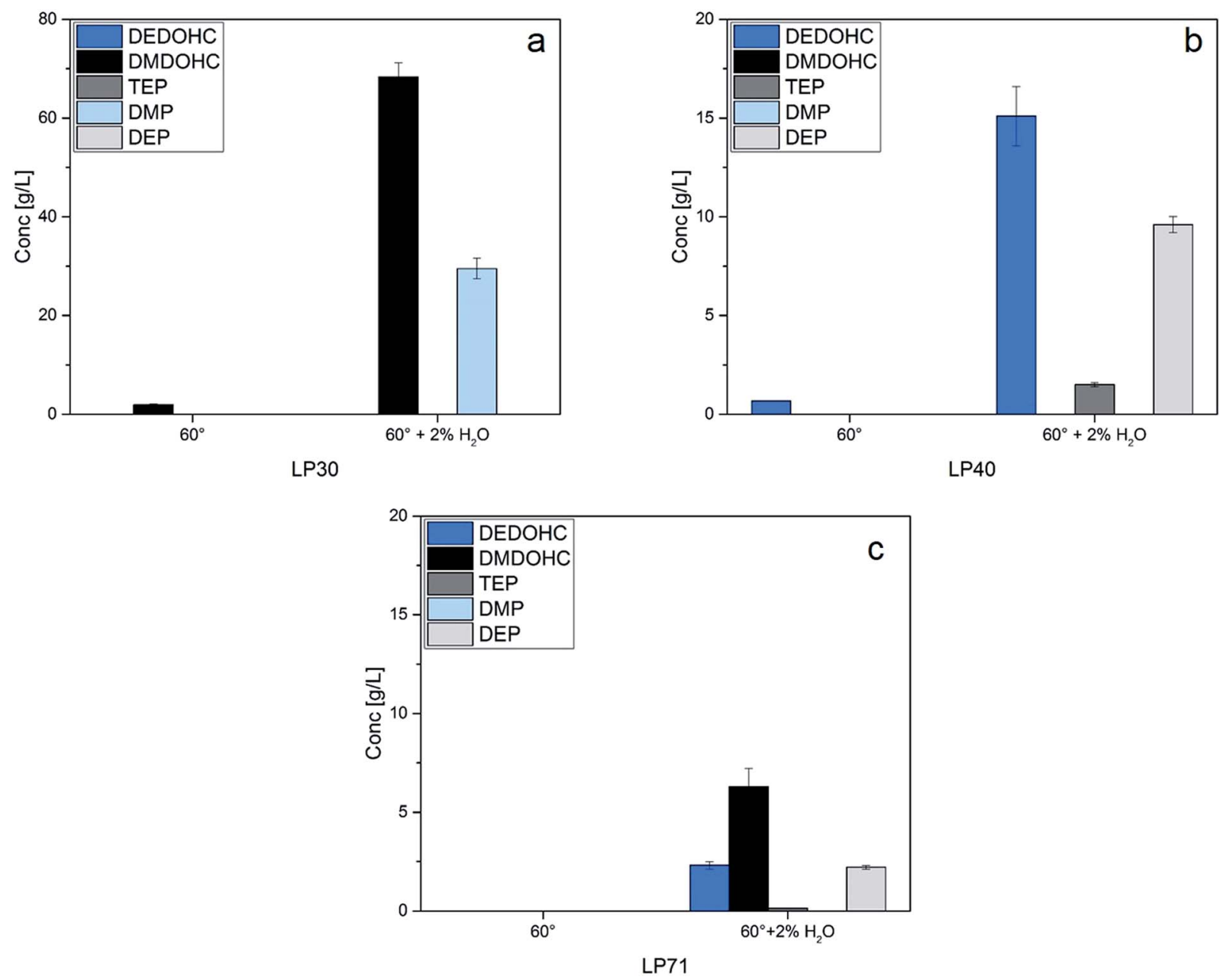

Fig. 2 Quantification results of thermal aging at $60{ }^{\circ} \mathrm{C}$ and thermal aging at $60{ }^{\circ} \mathrm{C}$ with 2 vol\% water determined for the electrolytes LP30 (a), LP40 (b) and LP71 (c).

electrolyte also may decompose or be less present in the electrolyte due to their incorporation in a more inorganic SEI during cycling of the cell at higher temperatures.

3.2.2.2 Cycling at higher cut-off potentials. All half cells cycled at higher cut-off potentials contained LP 50 . The aging product quantification results after cycling are shown in Table 5. In the half cells cycled to an upper cut-off potential of $4.95 \mathrm{~V} v$ s. $\mathrm{Li} / \mathrm{Li}^{+}, 15.6 \mathrm{~g} \mathrm{~L}^{-1} \pm 0.1 \mathrm{~g} \mathrm{~L}^{-1}$ DMDOHC and $24.1 \mathrm{~g} \mathrm{~L}^{-1}$ $\pm 1.2 \mathrm{~g} \mathrm{~L}^{-1}$ DEDOHC were found in the electrolyte. Compared to this, the cell with an upper cut-off potential of $5.20 \mathrm{~V} v s . \mathrm{Li} / \mathrm{Li}^{+}$, showed slightly increased amounts of DMDOHC and DEDOHC. In the cell cycled up to $5.6 \mathrm{~V} v$ s. $\mathrm{Li}^{2} \mathrm{Li}^{+}$, significant lower amounts

Table 5 Quantified amounts of DMDOHC, DEDOHC and TEP in half cells with different upper cut off-potentials $(4.95 \mathrm{~V}, 5.20 \mathrm{~V}$ and $5.60 \mathrm{~V}$ vs. $\left.\mathrm{Li} / \mathrm{Li}^{+}\right)$

\begin{tabular}{lllc}
\hline & $4.95 \mathrm{~V} v s . \mathrm{Li} / \mathrm{Li}^{+}$ & $5.20 \mathrm{~V}$ vs. $\mathrm{Li} / \mathrm{Li}^{+}$ & $5.60 \mathrm{~V} v$ v. $\mathrm{Li} / \mathrm{Li}^{+}$ \\
\hline DMDOHC $\left[\mathrm{g} \mathrm{L}^{-1}\right]$ & $15.6 \pm 0.1$ & $22.2 \pm 0.4$ & $7.9 \pm 0.9$ \\
DEDOHC $\left[\mathrm{g} \mathrm{L}^{-1}\right]$ & $24.1 \pm 1.2$ & $26.5 \pm 0.2$ & $3.8 \pm 0.5$ \\
TEP $\left[\mathrm{g} \mathrm{L}^{-1}\right]$ & $<$ LOD & $<$ LOD & $0.15 \pm 0.01$
\end{tabular}

of DMDOHC and DEDOHC were found. Furthermore, in this cell, $0.15 \mathrm{~g} \mathrm{~L}^{-1} \pm 0.01 \mathrm{~g} \mathrm{~L}^{-1}$ TEP were detected. The difference in the values for DMDOHC and DEDOHC was referred to the nonoptimal behavior of the cell cycled at $5.60 \mathrm{~V} v s$. $\mathrm{Li}^{\prime} / \mathrm{Li}^{+}$due to the very abusive conditions as LNMO is usually only cycled up to $<5 \mathrm{~V}$ vs. $\mathrm{Li} / \mathrm{Li}^{+}{ }^{+}{ }^{40,41}$

\section{Conclusions}

This work presented a LC-MS/MS technique for the quantification of LIB electrolyte main constituents as well as for selected aging products. All electrolyte constituents, including the organic carbonates and different types of aging products were successfully separated on the $\mathrm{C}_{18}$-PFP column and their amount in the electrolytes was quantified when present above the LOQ. The LODs, LOQs and recovery rates of all quantified substances were determined. The MRM mode was used in order to achieve the highest sensitivity. The comprehensive quantification was limited by a low number of commercially available standard substances. Due to this limit, a quantitative approach with the determination of the peak areas was conducted. 
For aging investigations, different aging strategies were applied to the electrolyte samples: thermal aging at $60{ }^{\circ} \mathrm{C}$, thermal aging at $60{ }^{\circ} \mathrm{C}$ together with 2 vol\% water, electrochemical aging at $20{ }^{\circ} \mathrm{C}$ and $60{ }^{\circ} \mathrm{C}$ and electrochemical aging at different upper cut-off potentials $(4.95 \mathrm{~V}, 5.20 \mathrm{~V}$ and $5.60 \mathrm{~V}$ vs. $\mathrm{Li} / \mathrm{Li}^{+}$). The quantification results showed clear trends. Thermal aging of LP30 led to the generation of DMDOHC, in LP40, DEDOHC was generated and in the samples containing LP71, DMDOHC and DEDOHC were quantified. In all cases, after thermal aging in the presence of 2 vol\% water, the amounts of DMDOHC and DEDOHC were significantly increased and organophosphate-based aging products were generated and quantified. Accordingly, the amount of main constituents (EC, DMC and DEC) decreased with increasing amounts of aging products. The accelerated aging reactions were also correlated to a high water consumption at elevated temperatures. The results were confirmed by the quantitative approach, all signal areas from the investigated carbonatebased aging products showed an increase after thermal aging with water. Electrochemical aging with increasing cutoff potentials showed slightly elevated amounts of DMDOHC and DEDOHC in the cell cycled at $5.20 \mathrm{~V} v s$. $\mathrm{Li} / \mathrm{Li}^{+}$compared to $4.95 \mathrm{~V} v s$. $\mathrm{Li} / \mathrm{Li}^{+}$. Only in the cell with a cut-off potential about $5.60 \mathrm{~V}$ vs. $\mathrm{Li} / \mathrm{Li}$, TEP was generated in sufficient amounts above the LOQ. Interesting results occurred in the case of investigated LIB full cells cycled at $20{ }^{\circ} \mathrm{C}$ and $60{ }^{\circ} \mathrm{C}$. Compared to the cells cycled at $20^{\circ} \mathrm{C}$, in all cells cycled at $60{ }^{\circ} \mathrm{C}$, the amount of these aging products significantly decreased.

In general, the combination of this developed LC-MS/MS technique for the quantification of LIB electrolyte substances with the previous work about structural elucidation with LC-ITTOF-MS, offers a comprehensive LIB electrolyte analysis with LC-MS (Fig. 3). The comprehensive and powerful analysis allows the structural elucidation and quantification of electrolyte constituents as well as the correlation to the different aging procedures (Fig. 4).
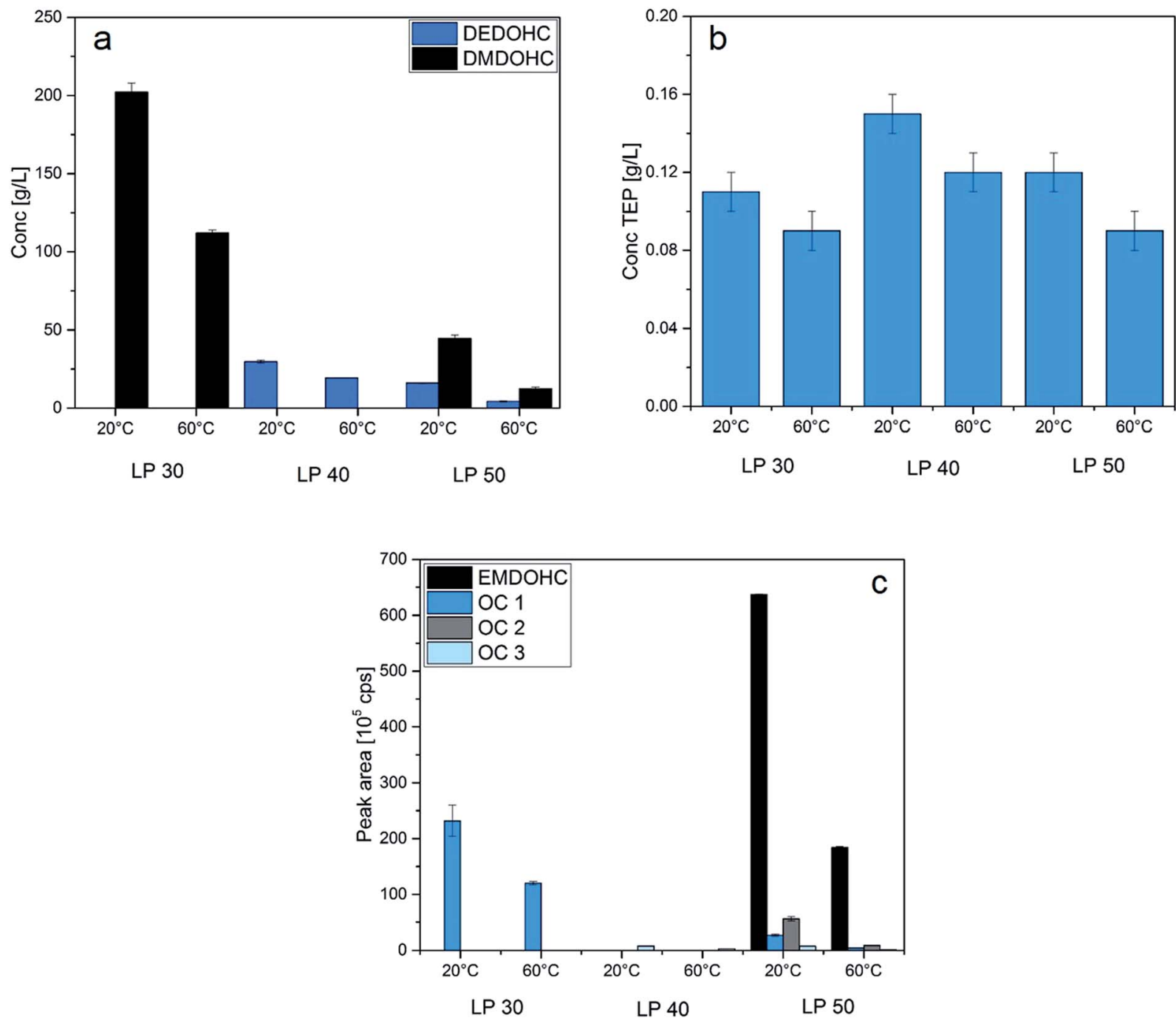

Fig. 3 Quantification results for DEDOHC and DMDOHC (a) and TEP (b) together with the quantitative approach (c) of the cells with LP30, LP40 and LP50, cycled at $20^{\circ} \mathrm{C}$ and $60^{\circ} \mathrm{C}$. 


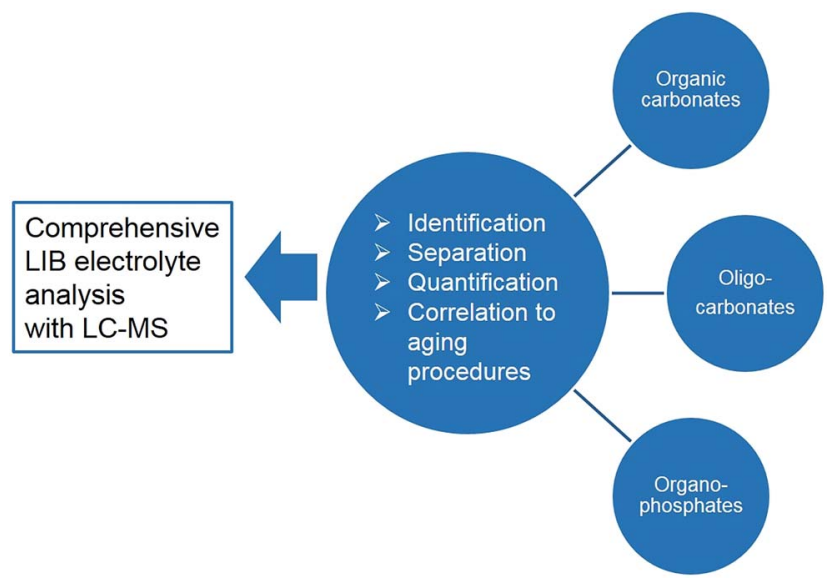

Fig. 4 Schematic representation of the combined results from the LC-IT-TOF-MS and the LC-MS/MS techniques offering a comprehensive LIB electrolyte analysis.<smiles>CCOP(=O)(O)OCC</smiles>

Fig. 5 Structures of DMP (left), DEP (middle) and TMP (right). The possible formation pathways were already discussed in literature. ${ }^{24,26,48,49}$

\section{Acknowledgements}

The authors thank the Lab4You Team from Shimadzu Europa $\mathrm{GmbH}$ in Duisburg for offering the possibility to work with the devices in the Shimadzu Laboratory World and for the competent support of the product specialists. The authors acknowledge the Federal Ministry of Education and Research for funding the Project "Elektrolytlabor" (03X4632).

\section{References}

1 M. Winter and J. O. Besenhard, Chem. Unserer Zeit, 1999, 33, 320-332.

2 R. Wagner, N. Preschitschek, S. Passerini, J. Leker and M. Winter, J. Appl. Electrochem., 2013, 43, 481-496.

3 J. Vetter, P. Novák, M. R. Wagner, C. Veit, K. C. Möller, J. O. Besenhard, M. Winter, M. Wohlfahrt-Mehrens, C. Vogler and A. Hammouche, J. Power Sources, 2005, 147, 269-281.

4 C. K. Dyer, P. T. Moseley, Z. Ogumi, D. A. J. Rand, B. Scrosati and J. Garche, Encyclopedia of Electrochemical Power Sources, Elsevier Science, 2013.

5 K. M. Abraham, Electrochim. Acta, 1993, 38, 1233-1248.

6 P. B. Balbuena and Y. Wang, Lithium-Ion Batteries: SolidElectrolyte Interphase, 2004.

7 R. W. Schmitz, P. Murmann, R. Schmitz, R. Müller, L. Krämer, J. Kasnatscheew, P. Isken, P. Niehoff, S. Nowak, G.-V. Röschenthaler, N. Ignatiev, P. Sartori, S. Passerini,
M. Kunze, A. Lex-Balducci, C. Schreiner, I. Cekic-Laskovic and M. Winter, Prog. Solid State Chem., 2014, 42, 65-84.

8 K. Tasaki, A. Goldberg and M. Winter, Electrochim. Acta, 2011, 56, 10424-10435.

9 M. Wakihara and O. Yamamoto, Lithium Ion Batteries: Fundamentals and Performance, Wiley-VCH Verlag $\mathrm{GmbH}$, Weinheim, 1998.

10 E. Krämer, T. Schedlbauer, B. Hoffmann, L. Terborg, S. Nowak, H. J. Gores, S. Passerini and M. Winter, J. Electrochem. Soc., 2013, 160, A356-A360.

11 M. Amereller, T. Schedlbauer, D. Moosbauer, C. Schreiner, C. Stock, F. Wudy, S. Zugmann, H. Hammer, A. Maurer, R. M. Gschwind, H. D. Wiemhöfer, M. Winter and H. J. Gores, Prog. Solid State Chem., 2014, 42, 39-56.

12 L. Terborg, S. Weber, S. Passerini, M. Winter, U. Karst and S. Nowak, J. Power Sources, 2014, 245, 836-840.

13 L. Terborg, S. Nowak, S. Passerini, M. Winter, U. Karst, P. R. Haddad and P. N. Nesterenko, Anal. Chim. Acta, 2012, 714, 121-126.

14 S. Wilken, M. Treskow, J. Scheers, P. Johansson and P. Jacobsson, RSC Adv., 2013, 3, 16359-16364.

15 M. Winter, Zeitschrift für Physikalische Chemie International journal of research in physical chemistry and chemical physics, 2009, 223, 1395.

16 K. Xu, Chem. Rev., 2004, 104, 4303-4418.

17 G. E. Blomgren, J. Power Sources, 1999, 81-82, 112-118.

18 L. Terborg, S. Weber, F. Blaske, S. Passerini, M. Winter, U. Karst and S. Nowak, Investigation of thermal aging and hydrolysis mechanisms in commercial lithium ion battery electrolyte, J. Power Sources, 2013, 242, 832-837.

19 A. V. Plakhotnyk, L. Ernst and R. Schmutzler, J. Fluorine Chem., 2005, 126, 27-31.

20 T. Kawamura, S. Okada and J.-i. Yamaki, J. Power Sources, 2006, 156, 547-554.

21 M. Grützke, V. Kraft, B. Hoffmann, S. Klamor, J. Diekmann, A. Kwade, M. Winter and S. Nowak, J. Power Sources, 2015, 273, 83-88.

22 C. Schultz, V. Kraft, M. Pyschik, S. Weber, F. Schappacher, M. Winter and S. Nowak, J. Electrochem. Soc., 2015, 162, A629-A634.

23 C. Schultz, Y. Qian, P. Niehoff, T. Schwieters, S. Nowak, F. M. Schappacher and M. Winter, J. Power Sources, 2016, 332, 60-71.

24 V. Kraft, W. Weber, B. Streipert, R. Wagner, C. Schultz, M. Winter and S. Nowak, RSC Adv., 2016, 6, 8-17.

25 R. Wagner, M. Korth, B. Streipert, J. Kasnatscheew, D. R. Gallus, S. Brox, M. Amereller, I. Cekic-Laskovic and M. Winter, ACS Appl. Mater. Interfaces, 2016, 8, 30871-30878.

26 W. Weber, V. Kraft, M. Grützke, R. Wagner, M. Winter and S. Nowak, J. Chromatogr. A, 2015, 1394, 128-136.

27 S. F. Lux, J. Chevalier, I. T. Lucas and R. Kostecki, ECS Electrochem. Lett., 2013, 2, A121-A123.

28 M. Tochihara, H. Nara, D. Mukoyama, T. Yokoshima, T. Momma and T. Osaka, J. Electrochem. Soc., 2015, 162, A2008-A2015.

29 J. H. Gross, Massenspektrometrie, Springer, Spektrum, 2013. 
30 C. Schultz, S. Vedder, M. Winter and S. Nowak, Spectroscopy Europe, Wiley, 2016, vol. 28, pp. 21-24.

31 H. F. Schroder, Compr. Anal. Chem., 2003, 40, 123.

32 U. Beyer, Analytik News, 2009.

33 L. Alder, 45th Florida Pesticide Residue Workshop, 2008.

34 F. Leng, C. M. Tan and M. Pecht, Sci. Rep., 2015, 5, 12967.

35 A. M. Andersson and K. Edström, J. Electrochem. Soc., 2001, 148, A1100-A1109.

36 F. Aricò and T. Pietro, Russ. Chem. Rev., 2010, 79, 479.

37 M. Peters, B. Köhler, W. Kuckshinrichs, W. Leitner, P. Markewitz and T. E. Müller, ChemSusChem, 2011, 4, 1216-1240.

38 P. Tundo, S. Memoli, D. Herault and K. Hill, Green Chem., 2004, 6, 609-612.

39 A. M. Andersson, M. Herstedt, A. G. Bishop and K. Edström, Electrochim. Acta, 2002, 47, 1885-1898.

40 A. Brandt, A. Balducci, U. Rodehorst, S. Menne, M. Winter and A. Bhaskar, J. Electrochem. Soc., 2014, 161, A1139-A1143.

41 X. Qi, B. Blizanac, A. DuPasquier, A. Lal, P. Niehoff, T. Placke, M. Oljaca, J. Li and M. Winter, J. Electrochem. Soc., 2015, 162, A339-A343.
42 S. E. Sloop, J. K. Pugh, S. Wang, J. B. Kerr and K. Kinoshita, Electrochem. Solid-State Lett., 2001, 4, A42-A44.

43 H. Yoshida, T. Fukunaga, T. Hazama, M. Terasaki, M. Mizutani and M. Yamachi, J. Power Sources, 1997, 68, 311-315.

44 T. Sasaki, T. Abe, Y. Iriyama, M. Inaba and Z. Ogumi, J. Power Sources, 2005, 150, 208-215.

45 T. Sasaki, S.-K. Jeong, T. Abe, Y. Iriyama, M. Inaba and Z. Ogumi, J. Electrochem. Soc., 2005, 152, A1963-A1968.

46 G. Gachot, S. Grugeon, G. G. Eshetu, D. Mathiron, P. Ribière, M. Armand and S. Laruelle, Electrochim. Acta, 2012, 83, 402409.

47 V. Kraft, M. Grützke, W. Weber, M. Winter and S. Nowak, J. Chromatogr. A, 2014, 1354, 92-100.

48 W. Weber, R. Wagner, B. Streipert, V. Kraft, M. Winter and S. Nowak, J. Power Sources, 2016, 306, 193-199.

49 V. Kraft, W. Weber, M. Grützke, M. Winter and S. Nowak, RSC Adv., 2015, 5, 80150-80157. 